\title{
Barbara JANKOWSKA
}

\section{Wpływ grup interesów na konkurencyjnoșć w świetle koncepcji rent-seeking}

\section{Wprowadzenie}

Jednym z głównych zagadnień badawczych nauk ekonomicznych jest współcześnie problem konkurencyjności, która jest bardzo różnie definiowana w literaturze. Jedna z definicji utożsamia konkurencyjność gospodarki ze zdolnością do zrównoważonego rozwoju w długim okresie [Transformacja 1995]. Stąd gospodarka bardziej konkurencyjna to gospodarka odnotowująca pozytywne zmiany we wskaźnikach makroekonomicznych i co się z tym wiąże zapewniająca dobrobyt społeczeństwu. Zarówno teoretycy, jak i praktycy gospodarczy szukają coraz to nowych dróg poprawy konkurencyjności, przede wszystkim na szczeblu mikro, a więc przedsiębiorstw, instytucji oraz makro, czyli na poziomie poszczególnych gospodarek narodowych. Mniej uwagi poŚwięca się obiektom i cechom poziomu mezo.

Niektórzy przedstawiciele nauk ekonomicznych zwracają uwagę, że w związku z postẹpującym rozwojem podmiotów i struktur średniego szczebla, niewłaściwym jest ograniczanie czynności badawczych tylko i wyłącznie do zjawisk i cech poziomów mikro czy makro [Gorynia 1995, Gajda 1996]. Wśród ekonomistów francuskich - np. F. Perroux i niemieckich - np. H.R. Peters można znaleźć zwolenników uznania mezoekonomii za samodzielną subdyscyplinę naukową. Wyodrę̧bnianie nowych poziomów analizy w ekonomii, a wśród nich poziomu mezo, skłania w związku z tym ku zastanowieniu się, czy w identyfikacji czynników sprawczych konkurencyjności gospodarki uzasadnione jest ograniczanie się tylko do zjawisk i charakterystyk typowych dla mikro- czy makropodmiotów. Warto zastanowić się, czy struktury, cechy i procesy typowe dla poziomu mezo mogą oddziaływać na konkurencyjność gospodarki.

Mezoekonomia ogniskuje uwagę badaczy na dotąd niedostrzeganych bądź co najmniej niedocenianych determinantach konkurencyjności gospodarki. Mezoanalizy dotyczą - ujmując rzecz w sposób uproszczony - zagadnień związanych z branżami czy regionami, a więc mezosystemami gospodarczymi. Na gruncie mezoekonomii podejmuje się m.in. problem społeczno-politycznych aspektów działania grup interesów, które można identyfikować z określonymi mezosystemami ${ }^{1}$. Wpływ grup nacisku na zrównoważony rozwój gospodarczy, a więc na konkurencyjność gospodarki daje się wyjaśnić i opisać m.in. przy pomocy teorii pogoni za rentą - teorii rent-seeking. W prezentowanym artykule

Barbara Jankowska jest doktorantką Akademii Ekonomicznej w Poznaniu.

1 Pojęcie grupy nacisku jest stosowane wymiennie z pojęciem grupy interesów. 
autorka wychodzi od wskazania negatywnych konsekwencji istnienia grup interesów w gospodarce, definiuje warunki sprzyjające przejmowaniu przez nie nieuzasadnionych rent, określa sposoby ograniczenia ujemnych skutków ich aktywności oraz próbuje dostrzec pozytywne strony ich funkcjonowania.

\section{Mechanizm oddziaływań grup nacisku na konkurencyjność gospodarki}

Rozwój przemysłowy i cywilizacyjny doprowadził do sytuacji, w której ludzie podzielający określony system przekonań czy wartości podejmują próby zorganizowania się przede wszystkim po to, aby skuteczniej artykułować swoje interesy. Dochodzi do formowania tzw. grup interesów. Należą do nich m.in. związki zawodowe, grupy biznesmenów, partie polityczne, stowarzyszenia branżowe, zrzeszenia środowisk religijnych czy etnicznych, itp. W literaturze przedmiotu można znaleźć teorie wyjaśniające, dlaczego ma miejsce tworzenie grup interesów P.A. Sabatier zaproponował nawet pewną klasyfikację tych teorii, przyjmując za kryterium wydzielania klas sposób organizowania grup interesów:

- teoria porządku i zaburzeń Trumana: kreowanie grup interesów to konsekwencja naturalnych interakcji i zaburzeń społecznych;

- teoria produktu ubocznego Olsona: grupy formują się tylko w sytuacji istnienia niewielu beneficjentów wymiany politycznej oraz niskich kosztów organizacyjnych;

- teoria wymiany Salisbury'ego: grupy są organizowane przez działaczy, którzy poszukują posady i korzyści materialnych;

- szersza teoria wymiany: grupy interesów organizują się pod wpływem aktywności wielu podmiotów, tj. przedsiębiorców, organizacji rządowych i fundacji;

- teoria zaangażowania: tworzenie grup interesów to wynik świadomej, celowej działalności jednostek ludzkich lub organizacji, których aktywność grupowa wynika z „wiary w słuszną sprawę” [Sabatier 1992].

Zanim bliżej przyjrzymy się grupom nacisku i ich aktywności należy podkreślić, że dyskutowana niżej interwencja państwa w życie gospodarcze, która po części przejawia się w praktykach protekcjonistycznych w odniesieniu do rodzimych podmiotów gospodarczych, nie zawsze powinna być wiązana z działaniem grup nacisku. Możliwe są sytuacje, w których całe społeczeństwo bẹdzie domagać się interwencji w celu poprawy swojego dobrobytu. Nie można więc interwencjonizmu państwowego utożsamiać zawsze tylko i wyłącznie z aktywnością grup nacisku, a nawet jeśliby rzeczywiście bodźcem do interwencji były posunięcia grup interesów, to nie zawsze muszą one być przejawem pogoni za nieuzasadnioną rentą².

2 Dzialalność grup nacisku może wyzwolić aktywność państwa, która przyczyni się do poprawy dobrobytu społecznego, np. pozytywnie można oceniać aktywność grup nacisku świadomych zagrożeń środowiska czy występujących w obronie praworządności. Nieco więcej o dobroczynnym wpływie grup nacisku na konkurencyjnošc gospodarki w następnym punkcie. 
Grupy interesów mogą wywierać tak negatywny, jak i pozytywny wpływ na konkurencyjność gospodarki. Ich działalność jest w literaturze utożsamiana z lobbingiem. Podkreśla się także, że ksztaftuje ona instytucjonalno-prawne otoczenie pojedynczych podmiotów gospodarczych, na konkurencyjności których opiera się konkurencyjność gospodarki [Jasiecki, Molęda-Zdziech, Kurczewska 2000, s. 16] ${ }^{3}$. Otoczenie to może sprzyjać podnoszeniu konkurencyjności gospodarki bądź być źródłem poważnych barier utrudniających jej poprawę.

Lobbing to inaczej rzecznictwo interesów. Trudno znaleźć jedną uniwersalną definicję tego pojęcia, choć daje się wyodrębnić kilka elementów łączących poszczególne określenia [Jasiecki, Molęda-Zdziech, Kurczewska 2000, s. 17]. Po pierwsze, rzecznictwo interesów polega na wywieraniu wpływu na proces decyzyjny w instytucjach władzy państwowej. Po drugie, sprowadza się ono do przekonywania, dostarczania i pozyskiwania informacji w celu promocji określonych decyzji, działań lub rozwiązań. Po trzecie, adresatem takiej działalności sa przede wszystkim decydenci i ich współpracownicy, piastujący funkcje publiczne. Tak zinterpretowane rzecznictwo interesów należy odróżnić od innych form wywierania nacisku na decydentów, które sprowadzają się do łamania prawa, odrzucania lub przekraczania norm moralnych (łapówki, handel wpływami, itp.).

Lobbing jako forma aktywności grup interesów budzi zwykle ambiwalentne skojarzenia. Obok głosów na temat pozytywnych efektów lobbystycznej aktywności grup nacisku, pojawiają się głosy przeciwników lobbingu. Podkreśla się, że:

- niekontrolowana działalnosć lobbystów może uwikłać przedstawicieli władz w bezpośrednie zależności od grup interesów, które nierzadko przybierają postać patologii instytucjonalnych - wykorzystywanie władzy dla celów prywatnych, korupcja, obniżenie sprawności państwa, co w efekcie może prowadzić nawet do kryzysu państwa przejawiającego się w niemożności kierowania administracją rządową;

- grupy interesów mogą podważać ład demokratyczny, ograniczając dostęp do pewnych stanowisk i dóbr oraz powierzać podejmowanie decyzji strategicznych osobom, które nie są odpowiedzialne przed wyborcami;

- niebezpieczną sytuacją jest uzależnienie państwa od zagranicznych grup nacisku, a więc np. inwestorów zagranicznych, którzy swoim interesom podporządkują lokalne rynki i potencjalne możliwości rozwoju danej gospodarki;

- nieliczna wpływowa grupa może narzucić politykę sprzeczną z interesem większości, gdyż grupy nacisku są zainteresowane bardzo ograniczonym zakresem spraw, pomijając interes państwa jako całości [Jasiecki, Molęda-Zdziech, Kurczewska 2000, s. 23].

3 Podmiotem prowadzącym lobbing może być obok grup nacisku także pojedyncze przedsiębiorstwo. 
Negatywne konsekwencje działań grup nacisku, a więc działań tylko we własnym interesie, który nierzadko jest sprzeczny z interesem większej czẹści społeczeństwa, dają się wyjaśnić przy wykorzystaniu teorii pogoni za rentą. Grupy nacisku podejmując określone działania mogą wpływać na kształt polityki gospodarczej, co umożliwia im czerpanie korzyści kosztem innych grup bądź nawet dobrobytu całego społeczeństwa. Instytucje państwa są wówczas wykorzystywane dla realizacji partykularnych celów $w^{4}$. Badania teoretyczne i empiryczne dowodzą, że jeśliby ograniczyć straty powodowane przez pogoń za rentą, to doszłoby do znacznej poprawy efektywności gospodarki i dobrobytu społecznego [Raczyński 1999].

Istnienie grup nacisku i ich wplyw na konkurencyjność gospodarki poprzez mechanizm rent-seeking nie jest z pewnością zjawiskiem rzadkim. Przykładów dostarcza rzeczywistość gospodarcza: nierentowne przedsiębiorstwa sektora publicznego zrzeszają się i domagają się podwyższenia subwencji, firmy małe i średnie żądają preferencyjnych kredytów, obawiający się utraty zatrudnienia pracownicy nierentownej branży gospodarki narodowej podejmują strajk, związki zawodowe domagają się podwyżek plac dla pracowników, itp. Zjawiskiem często występującym w życiu gospodarczym są naciski ze strony producentów krajowych na administrację państwa w celu wprowadzenia instrumentów ochronnych przed konkurencją zagraniczną. Początkowo mówi się oczywiście tylko o ochronie przejściowej i minimalnej, która ma pozwolić producentom krajowym na poprawę własnej sytuacji finansowej i stopniowe przygotowanie się do podjęcia walki konkurencyjnej z zagranicznymi producentami. W rzeczywistości ochrona przejściowa przeradza się w permanentną, a chronione przedsiębiorstwa nie poprawiają jakości swoich wyrobów i daleko im do dyscypliny w zakresie kosztów. Ubytek w dobrobycie społeczeństwa jest więc zauważalny. W obszarze konkurencyjności tych firm, a co za tym idzie gospodarki, nie dokonują się pozytywne zmiany ${ }^{5}$. Wydaje się, że właśnie sfera wymiany gospodarczej z zagranicą stwarza szczególnie przyjazne warunki dla wystąpienia pogoni za rentą i działalność grup interesów jest w tej sferze niezwykle widoczna.

W Polsce zjawisko rent-seeking i uaktywnienie się wielu grup nacisku w obszarze handlu zagranicznego można obserwować od 1990 roku, a więc po zniesieniu monopolu handlu zagranicznego i podjęciu działań w kierunku transformacji polskiej gospodarki, która wiązała się z coraz większym jej otwieraniem. Gospodarka polska została postawiona przed koniecznością liberalizacji obrotów handlowych z zagranicą, co w praktyce oznaczało obniżenie

4 Pod pojęciem instytucji autorka ma na myśli nie tylko wszelkie organizacje, ale także formalne i nieformalne reguły postępowania. Jest to definicja instytucji charakterystyczna dla nowej ekonomii instytucjonalnej.

5 Na przykładzie krajów rozwijających widać, że ochrona branż bẹdących w pierwszej, ewentualnie drugiej fazie cyklu życia (tzw. infant industries) rzadko prowadzila do rzeczywistego wzmocnienia tych galęzi na tyle, aby mogly podjąć w miarę wyrównaną walkę konkurencyjną z przedsiębiorstwami z zagranicy. [Rosati 1998, s. 297]. 
bądź nawet zniesienie tak ograniczeń taryfowych, parataryfowych, jak i pozataryfowych. Obowiązujące w Polsce cła, opłaty wyrównawcze, subwencje, koncesje, kontyngenty oraz licencje przywozu czy wywozu, skutecznie ograniczały wymianę gospodarczą z zagranicą, stwarzając równocześnie szanse czerpania rent przez niektóre grupy interesów. Każdorazowa próba ograniczenia protekcjonizmu w polskim handlu zagranicznym była $\mathrm{i}$ jest po dzień dzisiejszy przedmiotem sporów politycznych ${ }^{6}$. Przeciwnicy liberalizacji nierzadko reprezentują interesy określonej grupy producentów obawiających się zagranicznych rywali handlowych. Tymczasem w literaturze przedmiotu dowodzi się, że stosowanie ceł, środków para- i pozataryfowych generuje w większości przypadków straty netto (wynik pomniejszenia korzyści producentów i budżetu państwa powstałych w związku z wprowadzeniem wspomnianych barier o straty konsumentów) po stronie kraju, który je wprowadził7.

Grupy reprezentujące interesy branż zagrożonych masowymi zwolnieniami upatrują w protekcjonizmie szansę na zwięekszenie zatrudnienia i produkcji na rynku krajowym w wyniku przesunięcia popytu z dóbr importowanych na krajowe. Podwyższenie krajowej produkcji dóbr objętych ochroną ma rzekomo w wyniku działania efektów mnożnikowych doprowadzić do wzrostu całkowitej produkcji krajowej, co wiąże się ze wzrostem zatrudnienia. Sprawa jest jednak bardziej skomplikowana. Wprowadzenie np. ceł importowych generuje także wzrost cen dóbr krajowych m.in. dlatego, że producenci krajowi w obliczu dużej nadwyżki popytu na dobra krajowe nie są w stanie podnieść podaży do poziomu zapewniającego równowagę na rynku tego dobra. Często więc ma miejsce wzrost ceny dobra krajowego. Poza tym partnerzy zagraniczni, przeciwko którym dane bariery są wymierzone mogą przystąpić do odwetu, co w efekcie negatywnie wpłynie na międzynarodową konkurencyjność dóbr eksportowanych przez kraj, który zainicjował aktywność protekcjonistyczną.

Grupy nacisku obawiające się bezrobocia w związku z napływem na ich rynek pracy taniej sily roboczej również domagają się ochrony. Z sytuacją taką mamy do czynienia np. w przypadku niemieckiej branży budowlanej, która jest aktywnie chroniona przez władze RFN. Taka ochrona w ujęciu długookresowym nie służy poprawie konkurencyjności danej gospodarki. Przedsiębiorstwa zostają utwierdzone w przekonaniu, że drogą do poprawy konkurencyjności jest obniżka kosztów pracy - kosztów przypadających na jednego zatrudnionego, a zapomina się o potrzebie podnoszenia wydajności pracy.

Warto też zauważyć, że stosowaniem pewnych barier w handlu zagranicznym, a szczególnie barier taryfowych np. w Polsce są zainteresowani niektórzy przedstawiciele służb celnych. Oczywiście nie można generalizować, ale w ramach tych służb dałoby się także zidentyfikować grupę zainteresowaną

6 Argumenty za i przeciw protekcjonizmowi są prezentowane w oparciu o: [Budnikowski 2001. s. 214-227].

7 Omówienie mechanizmu dzialania wspomnianych środków i wykazanie, że ich wykorzysty. wanie prowadzi do strat netto w krajach je stosujących można znaleźć w: [Budnikowski 2001, s. 165-207]. 
utrzymaniem tych ograniczeń. Powszechnie mówi się o ogromnych stratach budżetu państwa, które są następstwem nielegalnego przywozu szeregu towarów na polski obszar celny. Określona część „administracji celnej” czerpie więc nieuzasadnione renty kosztem dobrobytu całego społeczeństwa.

Wymienione sytuacje i im podobne okoliczności stanowią poważną groźbę dla suwerennego procesu podejmowania decyzji w obszarze polityki gospodarczej państwa. Intensyfikacja działań grup interesów może doprowadzić nawet do destrukcji rynku, a wpływając na wysokość kosztów przedsiębiorstw czy wydatków i wplywów budżetowych odbije się negatywnie na konkurencyjności gospodarki.

Ujemne następstwa lobbingu ze strony grup interesów nazywa Olson blokadą grup interesów [McFarland 1992]. Blokada grup interesów oznacza, że dobrze zorganizowane grupy nacisku przejmują kontrolę nad polityką rządu, przy czym każda z nich oddziałuje w zakresie własnych zainteresowań [McFarland 1992]. Wielość grup interesów utrudnia więc wypracowanie programów, które służyłyby celom ogólnogospodarczym, np. poprawie konkurencyjności gospodarki.

Należy jednak zauważyć, że negatywny wpływ grup nacisku na konkurencyjność gospodarki poprzez mechanizm rent-seeking nie jest moźliwy bez choćby wymuszonej akceptacji po stronie państwa. Interakcje między grupami nacisku a agendami rządowymi, które określa się mianem mediatyzacji, mogą być zalegalizowane, a więc uprawomocnione bądź nieprawomocne [Jakóbik 2000, s. 89]

Formą legalizacji grup interesów jest korporatywizm (inne thumaczenie korporacjonizm [Gorynia 1995, Ehrlich 1985, Moore, Booth 1989]), który zawęża zbiór uprawomocnionych, a więc w pewnym sensie uprzywilejowanych grup interesów oraz integruje te grupy z aparatem władzy w państwie. Według A. Cawsona „korporatywizm to szczególny proces społeczno-polityczny, w którym organizacje reprezentujące monopolistyczne interesy funkcjonalne wdają się z agendami państwowymi w polityczną wymianę przynoszącą efekt w postaci, z jednej strony, pewnych decyzji politycznych i z drugiej strony, nadania owym organizacjom dwoistej roli: reprezentantów interesów i realizatorów uzgodnionej polityki" [Cawson 1995, s. 177]. Korporatywizm może rozwijać się na różnych poziomach, ale ostatnio podkreśla się, że coraz bardziej na znaczeniu zyskuje szczebel pośredni między mikro a makro. Mezokorporatywizm ogniskuje swoje zainteresowania na procesach reprezentacji i ochrony interesów, podejmowania decyzji politycznych i ekonomicznych dotyczących organizacji i zrzeszeń przedsiębiorstw branżowych, sektorowych czy grup zawodowych ${ }^{8}$.

Państwo z jednej strony ubolewa nad zjawiskiem pogoni za rentą, z drugiej stwarza przyjazne warunki dla pojawienia się rent-seeking. Główną przy-

8 Cawson twierdzi, że „Rozróżnienie pomiędzy makro, mezo- i mikro (korporatywizmem) dotyczy poziomu, na którym funkcjonuje organizacja interesu" [Cawson 1995, s, 177]. Zdaniem autorki rozróżnienie na makro-, mezo-, oraz mikrokorporatywizm można przeprowadzić według szczebla, którego dotyczą cele działania danej grupy interesów i ten sposób spojrzenia jest preferowany: jeśli są to cele dotyczące gospodarki jako całości, to mówimy o makrokorporatywizmie, analogicznie mikro- oraz mezokorporatywizm. 
czyną wystẹpowania pogoni za rentą jest przecież interwencja państwa w sferę gospodarki, która deformuje swobodne działanie mechanizmu rynkowego. Nie da się co prawda zaprzeczyć, że nawet we współczesnych gospodarkach rynkowych krajów wysoko rozwiniętych istnieją dziedziny, w które państwo musi się z oczywistych względów angażować, ale poziom tego zaangażowania i co za tym idzie interwencji, nie powinien znacznie wykraczać poza granice określane przez J.M. Buchanana mianem „państwa minimalnego" [Buchanan 1980b]. Zadania państwa, według Buchanana powinny się ograniczać do:

- ochrony osobistych i własnościowych praw jednostki,

- dbałości o przestrzeganie swobodnie zawartych kontraktów.

W przeciwieństwie do różnorodnych koncesji, ceł wwozowych, kontyngentów, licencji, itp. czynności te nie zniekształcają swobodnego działania mechanizmu rynkowego i nie generują działań w kierunku przejęcia rent.

Co determinuje wobec tego skłonność państwa do ulegania różnym grupom nacisku? Według E. Katza i J. Rosenberga nie bez znaczenia są słabe i mało wyraziste prawa własności [Katz, Rosenberg 1989, s. 133-144]. Antidotum na brak suwerennych decyzji państwa jest więc ostre nakreślenie praw własności ${ }^{9}$.

Próby przejmowania nieuzasadnionych rent są także tym bardziej prawdopodobne, im częściej w przeszłości państwo ulegało naciskom poszczególnych grup. Wynika to z tego, że wywieranie wpływu na posunięcia administracji państwa bezpośrednio wiąże się z koniecznością ponoszenia wydatków. Skłonnóść grup interesów do zaakceptowania wydatków zależy zdaniem R. Michaelsa od oczekiwań ${ }^{10}$. Jeśli w przeszłości państwo wykazywało dużą skłonność do ingerencji w procesy rynkowe, to tym większa będzie gotowość obecnie podążających za rentą do „inwestowania” w ową pogoń. Jeżeli np. w przeszłości państwo dotowało branżę górniczą w danym kraju, to należy oczekiwać, że zrzeszenie przedsiębiorstw branżowych będzie skłonne przeznaczać duże środki na utrzymanie dotychczasowych dotacji, gdyż zgodnie z teorią Michaelsa doświadczenia z przeszłości uzasadniają oczekiwania, że dotacje znów się pojawią.

\section{Sposoby ograniczenia negatywnych skutków działań grup nacisku}

O tym, że pogoń za rentą może przyczyniać się do obniżki konkurencyjności gospodarki nie trzeba już przekonywać. Warto zastanowić się, czy istnieją sposoby ograniczenia niepożądanych następstw posuniẹć grup nacisku.

9 Problem sygnalizowany przez Katza i Rosenberga można bylo zaobserwować w Polsce szczególnie w pierwszych latach transformacji gospodarki. Wyznacznikiem transformacji są m.in. procesy prywatyzacyjne, których efektem są mocne prawa własności, ograniczające bądż nawet przekreślające możliwości czerpania rent przez uprzywilejowane grupy. Wyjaśnia to oportunistyczne zachowania ze strony wielu grup nacisku - stowarzyszeń przedsiębiorstw branżowych czy związków zawodowych pracobiorców określonej branży, w miarę nasilania się procesów prywatyzacyjnych.

10 Michaels analizował wpływ różnych zmian przypuszczalnych (conjectural variations) na poziom wydatków przeznaczanych na pogoń. Pod pojęciem zmian przypuszczalnych należy rozumieć oczekiwania odnośnie do reakcji innych uczestników pogoni za renta, np. innych grup nacisku oraz oczekiwania co do zachowań regulacyjnych państwa [Michaels 1989, s. 31-39]. 
W literaturze przedmiotu można znaleźć kilka propozycji odnośnie tego problemu. G. Tullock postuluje konieczność zmniejszenia liczby uczestników pogoni za rentą, a wiẹc np. zredukowanie liczby grup nacisku [Tullock 1980, s. 104]. Proponuje on zwiększenie szans wygranej jednej grupy graczy kosztem innej grupy w drodze faworyzowania i preferencyjnego postępowania w stosunku do jednej z grup. Wprowadza do gry pojęcie stronniczości (bias). Rozwiązanie to budzi jednak wiele kontrowersji. Po pierwsze, przywileje dla jednej z grup niosą ze sobą koszty, po drugie takie rozwiązanie wydaje się niegodne moralnie. Po trzecie, pozostaje kwestią nierozstrzygniętą, kto miałby decydować o tym, która grupa powinna być faworyzowana.

Chęć poprawy dobrobytu społeczeństwa, co w ujęciu długookresowym wiąże się z koniecznością poprawy konkurencyjności gospodarki, wymaga po pierwsze uświadomienia sobie przez społeczeństwo istnienia sytuacji określanych mianem pogoni za rentą. Niezbędne jest wobec tego informowanie społeczeństwa o sytuacjach, w których dochodzi do naruszenia jego interesów. Wspomniany Tullock wymienia konkretne sytuacje, w których dojdzie do ograniczenia negatywnych skutków działań podejmowanych przez grupy interesów, pod warunkiem, że spoleczeństwo będzie o nich poinformowane:

- wydatkowanie środków z budżetu państwa w sposób korzystny dla określonej grupy nacisku, a nie przynoszący żadnych korzyści zwykłemu podatnikowi,

- posunięcia mające na celu podniesienie cen powyżej poziomu rynkowego w drodze np. ustanowienia cen minimalnych,

- popieranie przedsięwzięć monopolizacyjnych poprzez ograniczanie dostępu do danego rynku [Tullock 1984, s. 21-26]

Natomiast według K.J. Koforda i D.C. Colandera niezbędne dla eliminacji z rzeczywistości gospodarczej pogoni za rentą są ograniczenia konstytucyjne nakładane na swobodę decyzji politycznych w tych sferach, które są najbardziej podatne na rent-seeking. Zaliczają oni do nich:

- protekcjonistyczne praktyki w wymianie międzynarodowej,

- regulacje cenowe,

- subsydia i dotacje dla wybranych grup producentów i konsumentów dokonywane z budżetu państwa [Koford, Colander 1984, s. 212-214]

Skuteczność barier konstytucyjnych pozostawia jednak dużo do życzenia. J.T. Bennet i T.J. DiLorezo dowodzą, że politycy w celu sfinansowania przedsięwzięć służących określonym grupom nacisku potrafią wykorzystywać środki pozabudżetowe, a mianowicie tworzą różnorodne agencje, fundusze, przedsiębiorstwa z udziałem kapitału publicznego, udzielają gwarancji kredytowych [Bennet, DiLorezo 1982, s, 1153-1161]. Receptẹ na eliminację negatywnych następstw działania grup nacisku podaje także Buchanan. Próby likwidacji przywilejów gospodarczych przyniosą tylko wówczas zamierzony skutek - eliminację pogoni za rentą, gdy będą dotyczyć wszystkich grup interesów [Buchanan 1980a, s. 364-369]. Buchanan zauważa, że sytuacją korzystniejszą i nawet bardziej sprzyjającą całkowitej neutralizacji rent-seeking jest istnienie dużej, a nie małej liczby grup interesów. Wyjaśnia on, że w miarę rozprzestrzeniania się pogoni za rentą każda z grup nacisku jest częściej poszkodowanym ponoszącym straty niż beneficjentem korzyści, a więc im więcej poszkodowanych 
grup nacisku, tym większa skłonność do rezygnacji z „rent”. Każdy przywilej okazuje się być dla wielkiej liczby grup nacisku niekorzystny, a tylko dla pojedynczych grup korzystny. W związku z tym straty każdej z grup, z powodu istnienia pogoni za rentą, znacznie przewyższają korzyści osiągane przez te grupy za przyczyną rent-seeking. Wobec tego jednoczesne usunięcie wszystkich przywilejów byłoby korzystne dla każdej z grup interesów. Dokonałaby się tzw. „rewolucja konstytucyjna”.

Podobnie J.Q. Wilson oraz J. Walker twierdzili, że istnienie wielu grup nacisku jest lepsze niż funkcjonowanie niewielkiej ich liczby. Prowadząc badania nad zagadnieniami polityki regulacji i dotyczącymi grup interesów w Stanach Zjednoczonych, zidentyfikowali oni zjawisko tzw. przeciwwagi sił, które zapobiega kumulacji w dziedzinie gospodarki niepożądanych efektów działania grup nacisku [Wilson 1980, Walker 1983]. Zgodnie z teorią blokady grup interesów, najlepiej zorganizowane, silne ekonomicznie grupy nacisku usiłują kontrolować politykę rządu w zakresie domeny swego działania, jednak inne grupy starają się przeciwwaźyć siłę tych pierwszych. Zjawisko przeciwwagi sił wzmacnia więc pozycję władz państwa. Wilson, Walker i wspomniany wcześniej Buchanan byli więc zgodni co do tego, że im większa liczba grup nacisku, tym trudniej którejkolwiek z nich przejąć nieuzasadnione renty. Można oczekiwać, że w sytuacji, gdy danej grupie trudno jest zdobyć przywileje dla siebie, nie będzie ona chciała, aby wywalczyła je sobie jakakolwiek inna grupa. W ten sposób postawy grup, którym nie udaje się przejąć rent będą sprzyjały likwidacji rent-seeking.

Zastanawiając się nad sposobami ograniczania pogoni za nieuzasadnioną rentą warto jeszcze wspomnieć o związku pomiędzy koncentracją a skłonnością do wywierania nacisku. Koncentracja władzy, z jaką mieliśmy do czynienia w okresie gospodarki centralnie planowanej, sprzyjała przejmowaniu rent przez elity rządzące. Rozwiązaniem jest więc decentralizacja administracji państwowej, która przejawia się w przekazywaniu władzy na szczebel lokalny tworzenie władz samorządowych. Natomiast jeśliby skoncentrować rozważania na branży, to można stwierdzić, że jej koncentracja przejawia się w dominacji kilku przedsiębiorstw branżowych bądź w sytuacjach ekstremalnych jednego z nich. Dominacja, którą moźna skwatyfikować posługując się miernikami siły rynkowej czy nawet monopolowej, może być osiągnięta poprzez stosowanie nieuczciwych praktyk konkurencyjnych. Konieczne jest więc kontrolowanie przez państwo postępowania przedsiębiorstw zajmujących w branży pozycję dominującą. Niezbędna okazuje się tutaj polityka konkurencji ${ }^{11}$.

\section{Dobroczynny wpływ grup interesów na konkurencyjnosé gospodarki}

Pozytywny wpływ grup interesów na konkurencyjność gospodarki można rozpatrywać poprzez pryzmat dodatnich efektów prowadzonego przez nie lobbingu. Zwolennicy rzecznictwa interesów podkreślają, że:

11 W tym momencie autorka abstrahuje od rozważań na temat właściwego kształtu polityki konkurencji. Można jedynie stwierdzić, że chodzi o politykę, która nie będzie zniekształcać dziatania mechanizmu rynkowego. 
- ułatwia ono rozwiązywanie konkretnych problemów środowiskowych; grupy nacisku zwracają uwagę na zagadnienia partykularne, które często mają poważne implikacje społeczne i gospodarcze, dodatkowo problemy te zwykle rozwiązuje się ponad podziałami politycznymi;

- stwarza ono plaszczyznę kontaktów pomiędzy reprezentantami elit rządzących a liderami środowisk nie włączonych w bezpośrednie sprawowanie władzy,

- niekiedy zmusza ono do podjęcia kwestii, które inaczej byłyby pomijane, ze względu na niechęć do podejmowania "niewygodnych" problemów;

- grupy nacisku pełniąc rolę pośrednika pomiędzy jednostką a państwem mogą przyczyniać się lepszego uwzględniania przez państwo interesów jednostek, co bẹdzie sprzyjało rozwojowi demokracji [Jasiecki, Molęda-Zdziech, Kurczewska 2000].

Pożądany efekt aktywności grup nacisku to przede wszystkim kreacja infrastruktury instytucjonalnej, której znaczenie dla poprawy konkurencyjności gospodarki jest artykułowane coraz częściej i wyraźniej. Z taką sytuacją mamy do czynienia w Polsce, gdzie od początku okresu transformacji podejmuje się próby tworzenia instytucji samorządowych. Instytucje te dotyczą konkretnych mezosystemów - regionów, branż, sektorów i ich kreacja jest po części zasługą aktywności grup interesów z nimi związanych.

Samorząd może przybierać różne formy w zależności od charakteru więzi, które łączą poszczególnych członków. Gdy jest to więź terytorialna to mówimy o samorządzie terytorialnym, gdy jest to więź gospodarcza, to mamy do czynienia z samorządem gospodarczym, a gdy więź ta wynika z wykonywanego zawodu, to jest to samorząd zawodowy [Wykrętowicz 1998]. Samorząd gospodarczy tworzą izby rzemieślnicze, izby rolnicze oraz izby przemysłowo-handlowe, które „znacznie lepiej rozumieją potrzeby przedsiębiorców i mogą [...] efektywniej spowodować swoją identyfikację ze środowiskami gospodarczymi niż organizacje rządowe" [Zieliński 1995, s. 40]. Samorząd gospodarczy jest reprezentantem, rzecznikiem, jak i organizatorem środowiska społecznego przedsiębiorców, opiniuje i rekomenduje akty prawne dotyczące działalności gospodarczej, za jego pośrednictwem przedsiębiorcy partycypują w pracach organów samorządu terytorialnego, dzięki niemu zyskują możność wpływania na decyzje lokalne. Samorząd gospodarczy ułatwia wzajemną wymianę doświadczeń, informacji gospodarczych, nawiązywanie kontaktów handlowych, poszukiwanie nowych rynków zbytu, organizowanie szkoleń, konferencji. Dodatkowo daje przedsiębiorcom szansę wpływania na kształt aktów prawnych i rozwiązań organizacyjnych, które mają współgrać z działaniami podejmowanymi przez firmy w celu poprawy swojej konkurencyjności. Drugi typ samorządu - samorząd zawodowy reprezentowany przez izby lekarskie, aptekarskie, adwokackie i inne ma za zadanie ochronę zawodów, które ze względu na dobro społeczne wymagają najwyższych kwalifikacji zawodowych i etycznych. Sprzyja on integrowaniu środowisk zawodowych, reprezentuje jego interesy, prowadzi szkolenia, określa i egzekwuje zachowywanie zasad etyki zawodowej oraz czuwa nad nale- 
żytym wykonywaniem zawodu. Natomiast samorząd terytorialny jest podstawową instytucją kierującą rozwojem lokalnym gminy czy miejscowości. Posiadając lepsze rozeznanie w potrzebach i warunkach lokalnych może podnosić konkurencyjność gospodarki w wymiarze regionalnym. Istotnym obszarem jego aktywności jest promocja danego regionu, która ulatwia przyciągnięcie przedsiębiorczych inwestorów.

Jak wcześniej sygnalizowano, obszarem szczególnie podatnym na rent-seeking jest sfera handlu zagranicznego. Wskazywano, że posunięcia protekcjonistyczne ze strony władz państwa podejmowane pod naciskiem grup interesów należy oceniać negatywnie. Ochrona poszczególnych branż gospodarki narodowej inicjowana przez aktywność grup nacisku nie jest jednak zawsze przejawem pogoni za nieuzasadnioną rentą. Obiektywizm wymaga wyodrębnienia tych postępowań ochronnych w zakresie międzynarodowej wymiany handlowej, które mają zabezpieczać zdrową rywalizację firm na rynku. W przeciągu ostatnich dwóch lat nasiliły się w Polsce oszustwa celne i w związku z tym przedstawiciele niektórych branż zaczęli domagać się od rządu większej ochrony przed nieuczciwą konkurencją zagraniczną (Tablica 1). Przejawy nieuczciwej konkurencji to unikanie płacenia cła, pobór niższego cła w wyniku zaniżania wartości celnej towaru i co się z tym wiąże, zaniżanie podstawy naliczania podatku VAT, brak oznaczenia na towarze i opakowaniu kraju pochodzenia oraz nazwy firmy importującej, brak informacji i instrukcji w języku polskim, atestów wymaganych przez polskie prawo, a także niespełnianie norm wymaganych od polskich producentów [Kaliszuk 2000, s. 318]. Nawoływanie do przeciwdziałania wymienionym praktykom należy ocenić pozytywnie szczególnie dlatego, że najczęściej wiąże się to ze zwalczaniem dumpingu. Przejawy nieuczciwej konkurencji nie służą konkurencyjności gospodarki polskiej, gdyż powodują zmniejszenie wpływów do budżetu państwa, które można by przeznaczyć na stymulowanie przedsiębiorczości i uniemożliwiają prowadzenie uczciwej walki konkurencyjnej, która jest bodźcem do poprawy konkurencyjności przez przedsiębiorstwa. Należy zauważyć, że większość $\mathrm{z}$ naciskających na protekcję związana jest z branżami znajdującymi się w procesie restrukturyzacji. Nie podjęcie działań ochronnych mogłoby więc zniweczyć dotychczas osiągnięte rezultaty.

\section{Podsumowanie}

Grupy nacisku stanowią nieodłączny element współczesnej rzeczywistości gospodarczej. Jak wynika z przeprowadzonych rozważań mogą wywierać tak pozytywny, jak i negatywny wpływ na konkurencyjność gospodarki. W literaturze przedmiotu podkreśla się, że całkowita bądź przynajmniej znaczna likwidacja ujemnych następstw ich aktywności przejawiającej się w pogoni za nieuzasadnioną rentą wydaje się być mało prawdopodobna [Raczyński 1999]. Stwarza to poważne zagrożenie dla rozwoju gospodarczego wielu organizmów państwowych, szczególnie dla krajów rozwijających się, gdzie natężenie rent-seeking jest niezwykle duże. 
Tablica 1

Postępowania ochronne wszczęte w Polsce w latach 1998-2000

\begin{tabular}{|c|c|c|c|c|}
\hline Lp. & Towar & Kraj & \begin{tabular}{|c|} 
Rok \\
wszczecia
\end{tabular} & Wynik postępowania \\
\hline 1. & Wegiel kamienny & Rosja & 1998 & kontyngent \\
\hline 2. & Obuwie & Chiny & 1998 & dodatkowa oplata celna \\
\hline 3. & Gliny ogniotrwale & Ukraina & 1998 & nieautomatyczna rejestracja \\
\hline 4. & Tkaniny syntetyczne & $\begin{array}{l}\text { Tajwan, } \\
\text { Republika } \\
\text { Korei }\end{array}$ & 1999 & $\begin{array}{l}\text { kontyngent w imporcie } \\
\text { z Tajwanu }\end{array}$ \\
\hline 5. & Blachy powlekane & $\begin{array}{l}\text { Wszystkie kraje } \\
\text { eksportujace do Polski }\end{array}$ & 1999 & postępowanie w toku \\
\hline 6. & $\begin{array}{l}\text { Przẹdza z włókien syntetycznych, } \\
\text { akrylowych oraz mieszanek tych } \\
\text { wlókien z welną lub cienką sierścią } \\
\text { zwierzeca }\end{array}$ & Litwa & 1999 & postepowanie w toku \\
\hline 7. & Saletra amonowa & Rosja & 1999 & $\begin{array}{l}\text { tymezasowa dodatkowa } \\
\text { oplata celna }\end{array}$ \\
\hline 8. & Przedza teksturowana z poliestrów & Turcja & 1999 & postepowanie w toku \\
\hline 9. & Blachy walcowane na gorąco & $\begin{array}{l}\text { Kazachstan, Rosja, } \\
\text { Ukraina }\end{array}$ & 1999 & postępowanie w toku \\
\hline 10. & $\begin{array}{l}\text { Ciagniki kołowe, rolnicze } \\
\text { i używane w leśnictwie }\end{array}$ & $\begin{array}{l}\text { UE, Czechy, Slowacja, } \\
\text { Rosja Bialoruś }\end{array}$ & 1999 & postępowanie w toku \\
\hline 11. & Zelazka elektryczne & Chiny & 2000 & postepowanie w toku \\
\hline
\end{tabular}

Źródło: E. Kaliszuk, Ograniczenia pozataryfowe w imporcie i eksporcie Polski, w: Zagraniczna polityka gospodarcza i handel zagraniczny Polski 1999-2000, red. J. Kotynski, IKiCHZ, Warszawa 2000, s. 319.

Rozpoznanie społeczno-politycznych konsekwencji istnienia w gospodarce grup interesów wydaje się być przydatne krajom zmierzającym w kierunku pełnego urynkowienia gospodarki. Gospodarki centralnie zarządzane stwarzały bowiem ogromne możliwości przejmowania korzyści przez określone grupy interesów kosztem reszty społeczeństwa. M. Raczyński zauważa, że decyzje gospodarcze podejmowane w czasie panowania w Polsce gospodarki centralnie kierowanej były wynikiem przetargu grup interesów w obrębie szeroko pojętej władzy [Raczyński 1998]. Zjawisko wspomnianego przetargu jest ciągle żywe w sektorach publicznych poszczególnych gospodarek. Z jednej strony można zaobserwować, że w przypadku prób urynkowienia niektórych ze wspomnianych sektorów istnienie branżowych grup interesów: związków zawodowych, stowarzyszeń przedsiębiorstw branżowych, urzędników administracji państwowej „koordynujących” działania branży skutecznie to uniemożliwia. Rodzi to niebezpieczeństwo wytworzenia się niekonkurencyjnej, a nawet antykonkurencyjnej struktury gospodarki, co wyklucza zrównoważony rozwój gospodarczy, a więc nie służy poprawie konkurencyjności gospodarki. Z drugiej strony trzeba przyznać, że za przyczyną istniejących grup interesów tworzone są różnego rodzaju instytucje, których misja sprowadza się nie do wywierania nacisku na władzę państwa w celu pozyskania nieuzasadnionych 
rent, ale w konstruktywnej współpracy z tą władzą, co w efekcie ma zapewnić zdolność gospodarki do zrównoważonego rozwoju gospodarczego.

\section{Bibliografia}

Bennet J.T., DiLorezo, T.J., [1982]. The Political Economy of Political Philosophy: Discretionary Spending by Senators on Staff, American Economic Review, vol. 72.

Buchanan J.M., [1980a], Reform in Rent-Seeking Society, Toward a Theory of Rent Seeking Society, red. J.M. Buchanan, R.D. Tollison, G. Tullock, Cellege Station, Texas.

Buchanan J.M., [1980b], Rent Seeking and Profit Seeking, w: Toward a Theory of Rent Seeking Society, red. J.M. Buchanan, R.D. Tollison, G. Tullock, Cellege Station, Texas.

Budnikowski A., [2001], Międzynarodowe stosunki gospodarcze, PWE, Warszawa.

Cawson A., [1995], Wprowadzenie. Wielość korporatywizmów; o konieczności mediatyzacji interesów na szczeblu pośrednim, w: Wladza i spoleczeristwo, red. J. Szczupaczyński, Wydawnictwo Naukowe Scholar, Warszawa.

Ehrlich S., [1985], Oblicza pluralizmów, PWN Warszawa.

Gajda J.. [1996], Nowa rola mezoekonomii, w: Rola mezoekonomii w rynkowym systemie zarzqdzania gospodarkq, red. K. Górka, AE Kraków.

Gorynia M., [1995], Teoria regulacji mezosystemów gospodarczych a transformacja postsocjalistycznei gospodarki polskiej, AE Poznań.

Jakóbik W., [2000], Zmiany systemowe a struktura gospodarki w Polsce, PWN, Warszawa.

Jasiecki K., Molęda-Zdziech M., Kurczewska U., [2000], Lobbing, Oficyna Ekonomiczna, Kraków.

Kaliszuk E., [2000], Ograniczenia pozataryfowe w imporcie i eksporcie Polski, w: Zagraniczna polityka gospodarcza $i$ handel zagraniczny Polski 1999-2000, red. J. Kotyński, IKiCHZ, Warszawa 2000.

Katz E., Rosenberg J., [1989], Rent Seeking for Budgetary Allocation: Preliminary Results for 20 Countries, Public Choice, vol. 60.

Koford K.J., Colander D.C., [1984], Taming the Rent-Seeking, w: Neoclassical Political Economy. The Analysis of Rent-Seeking and DUP Activities, red. D.C. Colander, Ballinger Publishing Company. Podaję za: [Raczyński 1999].

McFarland A.S., [1992], Interest Groups and the Policymaking process: Sources of Countervailing Power in America, w: The Politics of Interest, red. M. Petracca, Westview Press, Boulder, San Francisco Oxford.

Michaels R., [1989], Conjectural Variations and the Nature of Equilibrum in Rent-Seeking Models, Public Choice, vol. 60.

Moore Ch., Booth, S., [1989], Managing Competition, Clarendon Press, Oxford.

Sabatier P.A., [1992], Interest Group Membership and Organization: Multiple Theories, w: The Politics of Interest, red. M. Petracca, Westview Press, Boulder, San Francisco Oxford.

Raczyński M., [1998], Pogoń za rentą a transformacja systemowa w Polsce, Ekonomista nr 2-3.

Raczyński M., [1999], Implikacje pogoni za rentą dla teorii regulacji, Gospodarka Narodowa. $\mathrm{nr} 1-2$.

Rosati D., [1998], Polska droga do rynku, PWE, Warszawa.

Transformacja systemowa a konkurencyiność przedsiębiorstwa, [1995], IRiSS, Warszawa.

Tullock G., [1980], Efficient Rent-Sekking, w: Toward a Theory of Rent Seeking Society, red. J.M. Buchanan, R.D. Tollison, G. Tullock, Cellege Station, Texas.

Tullock G., [1984], The Backward Society: Static Inefficiency, Rent Seeking, and the Rule of Law, w: The Theory of Public Choice II, red. J. Buchanan, R.D. Tollison, The University of Michigan Press. 
Walker J.L.. [1983], The Orgins of Maintenanace of Interest Groups in America, American Political Science Review, vol. 77.

Wilson J.Q., [1980], The Politics of Regulations, w: The Politics of Regulation, red, J.Q. Wilson, Basic Books, New York 1980. Podaję za: [ Jakóbik 2000].

Wykrętowicz S., (red.), [1998], Samorzqd w Polsce. Istota, formy, zadania, Wyd. WSB Poznań.

Zieliński L., [1995], Rola samorzq̨du gospodarczego w ksztaltowaniu środowiska spoleczego przedsiębiorców (na przykładzie Izby Przemysłowo-Handlowej w Gdyni), Poznań (maszynopis pracy doktorskiej, Biblioteka UAM w Poznaniu). 